\title{
The Problematic Issues of Sports Law in Latvia: Compliance of Labour and Tax Legislations from the Sustainable Development Perspective
}

\author{
By Karina Zalcmane ${ }^{1}$, Marina Kamenecka-Usova ${ }^{2}$, Atis Bickovskis ${ }^{3}$
}

\begin{abstract}
Sport performs several functions in society: an educational, a social, a cultural as well as a recreational function. Nevertheless, sport is also a business: in economic terms, it is a rapidly growing area accounting for $3 \%$ of world trade and is one of the sectors most likely to generate new employment in the near future (Colucci \& Hendrickx, 2014). For that reason, at the present stage of sustainable development of sports in Europe in general and in Republic of Latvia in particular, there is a growing need for a clear regulation of the employment relations of professional athletes and transparency of taxation in the sports industry. Taking these considerations into accounts, aim of the research paper is to assess the theoretical and practical issues related to employment relationships and taxation in Latvian sports from the sustainable development perspective. The methodological basis of the research consists of general scientific and special legal research methods.
\end{abstract}

Keywords: Employment relationship, tax law, professional athlete, sports law, sustainable development

\section{Introduction}

Sport performs several functions in society: an educational, a social, a cultural as well as a recreational function. Nevertheless, sport is also a business: in economic terms, it is a rapidly growing area accounting for 3\% of world trade and is one of the sectors most likely to generate new employment in the near future (Colucci \& Hendrickx, 2014).

Some authors have pointed out that exactly the essential economic importance of sports law is the basis for addressing the theoretical nature of sports law (Gardiner S., et al., 2012). It should be emphasized that the study of the peculiarities of sports labour law and taxes is considered to be one of the most important research directions of sports law as a whole, as the impact of sports on the sustainable development is unquestionable. Many sports legal issues are related with the legal status of athletes and the relationship between athletes and their teams or sport associations (Hendrickx, 2017). For example, the Bosman case, which is actually a labour case is part of Sports law theory already.

Moreover, professional athletes and federations are at the moment under the close scrutiny of the tax authorities, in view of the peculiarities of their activities. In the area of taxation, professional athletes constitute a special "risk group". There are three main reasons for this. Firstly, they often move and participate in competitions in various countries, the laws of which are usually very different, and sometimes several states at once may try to get 
their share of the tax from the same income. Secondly, usually the incomes of athletes are generally very high and therefore falls within the maximum tax rates in countries with a progressive tax system. And thirdly, their contracts and relocations are discussed in the press to the smallest detail, thus attracting additional attention of the tax authorities.

Taking these considerations into accounts the authors will focus on assessing the theoretical and practical issues related to employment relationships and taxation in Latvian sports from the sustainable development perspective.

\section{Methodology and Research Methods}

The methodological basis of the research consists of general scientific methods: monographic method, analytical method, comparative method and induction, deduction. In order to interpretate national, foreign and EU legislation in relation to the research question, the following legal translation methods (methods of interpretation) were used: grammatical, historical, teleological and systemic.

\section{Specifics of Sports Labour Law}

One of the main development tasks of sports in the Republic of Latvia in accordance to Sports policy guidelines for 2021-2027 (Latvijas Republikas Ministru kabineta tiesību aktu projekti, 2021) is to amend a Sports Law (legislative act), in order to create a new model of sports management. For the implementation of this task, authors assume, it is undoubtedly important to regulate various aspects of relations in the field of sports, including regulation of labour relations of athletes. In this matter, the experience of other countries is interesting, as these relations are differently regulated. The countries in which the legal regulation of the labour relations of athletes are carried out can be conditionally divided into three groups. The first group include the states in which these relations are regulated by labour laws (legislative act): Ireland, Czech Republic, Mexico, Chile; the second group includes countries in which legal regulation is fragmented and regulated by many different acts, mainly civil codes: Germany, Finland, Croatia, Sweden and the third group includes countries that allows an alternative regulation by an employment or civil contracts: Greece, Italy, Poland, Latvia, Spain, Portugal, France, Brazil.

Also, the authors would like to consider separately the case law of the UK in regards the labor relations of athletes, since England and Wales operate a common law system which combines the passing of legislation but also the creation of precedents through case law (Bodleian Libraries, 2021).

The first group of countries regulates labour relations through labour laws, for example, the Federal Law of Mexico "On Labour" 02.12.1969 contains Chapter 10 "Professional Athletes", it regulates the issues of wages of athletes, terms of conclusion of employment contracts with athletes, features of transfer to another sports organization, as well as some duties of athletes-workers and special grounds for termination of the employment contract (Rodríguez, 2014). Nevertheless, the provisions of the mentioned above chapter are established in relation to athletes involved only in a particular sport (football, handball boxing, etc.). From this it could be concluded that labour legislation regulates the 
employment of athletes of a certain kind of sport, therefore, other athletes either do not have the status of "professional" athletes, or their sports activities are regulated at the level of civil legislation.

The second group have more specific legal regulation of the employment issues in the sports industry. For instance, in Sweden there is no legislation regulating the employment of athletes, the model of labour law in this country is based on the self-regulation of these relations with the participation of trade unions and employers with minimal government involvement (Möller, 2020). It is at the level of collective agreements that working conditions, working hours, days off, minimum wages are determined.

The countries of the third group have in their legislation separate acts, devoted to the regulation of the sports industry in general and employment of athletes in particular. In Poland, there is no difference between an employment contract and a civil contract with an athlete. In the Polish Labour Code there are no special rules governing the work of athletes and coaches. At the same time, the Law of the Republic of Poland "On Sports" provides the basic concepts and provisions on contracts with athletes and coaches, which, regardless of their form (labour or civil), have certain characteristics (Dynowski \& Sałajczyk, 2020).

Moreover, there is a case law in regards to employment issues of professional athletes. For example, in 2016, the Polish Supreme Court concluded that where the remuneration is fixed (i.e., not dependent on the player's results), and the player is obliged to follow the club's instructions as to the time, place and activities performed (i.e., where the club takes the operational risk), the footballer is just a service provider acting under a service agreement, and not a genuine businessperson or sole trader (Dynowski \& Sałajczyk, 2020). Therefore, it is the football club's responsibility to calculate the social contributions and pay them on behalf of the footballer.

Italy also has a special sports law regulating the employment relationship of athletes. The Law of 03.23.1981 No. 91 "Legal bases of relations between sports organizations and professional athletes" regulates the form and terms of an employment contract, which is concluded for a period of up to 3 years and is subject to mandatory state registration (Colucci, 2014). It should be noted that the terms of this legislative act apply only to professional athletes.

The Sports Law of Latvia among the presented special laws of the countries of the third group to the least extent discloses the issue of regulating the employment of athletes. However, since the issue is not regulated either in the Labour Law or in other normative acts, the basic law for regulating the employment relationships of athletes is precisely the Sports Law (legislative act). It contains only two articles regulating the employment of athletes. Art. 19 gives a definition of a professional athlete, from which it follows that a professional athlete is a natural person, that on the basis of a contract of employment and for the agreed remuneration prepares himself or herself for sports competitions and participates therein and Art. 20 lists some of the rights and responsibilities of an athlete a sports employee shall follow the rules of international sports federations and sports federations recognised in Latvia, the principles of sports ethics and fair play, the rules of the anti-doping conventions, as well as laws and regulations (Sporta likums, 2002).

However, the definition of professional athletes actually creates numerous legal problems. Currently, due to inappropriate regulation, athletes are employed in Latvia on the basis of 
contractor agreement, royalty agreement, cooperation agreement and other agreements or act as a self-employed. Thus, from a legal point of view, these athletes are not considered as "professional athletes" within the meaning of the Sports Law. For that reason, the athletes are not provided with such social guarantees as if they were employed on the basis of an employment agreement.

The employment agreement in Latvia not only imposes obligations on the employee but also confers special rights such as the right to remuneration for the work performed, the right to social guarantees, the right to fair, safe and healthy working conditions, the right to paid annual leave, the right not to be discriminated against, the right to equal treatment and others (Darba likums, 2002). While performing job responsibilities, the employee is subordinated to the employer, therefore the interests of the employee are specially protected in regulatory enactments. A professional athlete in Latvia under any type of agreement has duty of obedience to the instructions of the employer. However, none of the mentioned above types of agreements gives the right or the objective possibility to realize several guarantees specified in the Labour Law.

For example, Article 149 of the Labour Law strengthens the right to paid annual leave (Darba likums, 2002). Under that provision, an employee is entitled to four calendar weeks of paid annual leave. The specifics of the work of a professional athlete do not allow to choose the time of vacation, while the "vacation" of a professional athlete is not paid during the free period of training and competitions.

The Labour Law also stipulates that upon termination of employment, the employee receives compensation for unused leave (Darba likums, 2002). The specificity of sports contracts is their short-term nature. Taking into account the interests, vision and plans of sports clubs, contracts with professional athletes are concluded only for a certain period of time. This means that each time such a contract expires, the athlete would be entitled to compensation for paid annual leave, as leave within the meaning of the Labour Law is not possible during the term of the professional athlete's contract. Moreover, this refers only to the employment agreement, not to any mentioned above. Therefore, there is no legal obligation for the club (employer) to pay compensation for unused leave.

The regulation of free time in the Labour Law of Latvia also provides the right to additional leave and leave in connection with the birth of a child. For example, the child's father is entitled to 10 calendar days' leave (Darba likums, 2002). Similarly, to the above, a professional athlete cannot use these guarantees provided by the Labour Law, in case he performs his responsibilities not under the employment agreement.

However, the most important distinguish of an employment agreement from other civil law contracts is its termination. In accordance with Article 101 of the Labour Law, the employer is entitled to terminate the employment relationship only on the grounds specified by law (Darba likums,2002). The employer must substantiate the reason for the termination of the employment relationship, as well as indicate the legal basis for the termination of this employment relationship. Often, the grounds for terminating a contract with a professional athlete are incompatible with those specified in the Labour Law, for example, failure to achieve the planned sports goals, the transfer of an athlete to another club, violation of discipline and other rules during free time, etc.

Finally, there are a number of individual athletes who do not have a contractual relationship with any employer (club). These are athletes who finance their preparation for 
and participation in competitions from their own resources. Such a model exists, for example, in tennis, martial arts, equestrian sports and elsewhere. At the same time, sport is the only income of these athletes.

As was mentioned above, for a correct assessment of the legal regulation of labour relations of athletes all over the world, including Latvia, it is also necessary to consider the case law of Great Britain. For that reason, authors have chosen the Jess Varnish Case for an analysis.

According to the facts analyzed by the U.K. Employment Tribunal in the case No. 2404219/2 from December 2018, Jess Varnish was a very talented British professional cyclist. She started racing when she was about seven years old. When she was a 12-yearold schoolgirl she was selected for the British Talent Team Programme which had been established by British Cycling Federation (hereinafter "British Cycling").

In 2006, whilst she was still at school Varnish was selected to join the World Class Programme (hereinafter "WCP") as a junior sprinter, aged 15. WCP was run by British Cycling. She was later promoted to the Olympic Academy Programme when she was aged 17. From this programme the Varnish was selected for the Olympic Podium Programme. British Cycling (the trading name of the British Cycling Federation) is:

a) a private company limited by guarantee;

b) the national governing body for cycle sport;

c) a not-for-profit organization;

d) not a public body;

e) a membership organization.

The objectives of British Cycling are to promote and control the sport of cycling in the UK. It supports the interests of its members through local clubs and privately organised racing meetings, through promotions and insurance policies. It issues race licenses. Individuals who wish to participate in competition must obtain a race license from it in order to compete. It oversees sporting competitions in the disciplines of road, track, BMX, mountain biking, cyclo-cross and cycle speedway and administers most competitive cycling in Great Britain.

In its most high-profile role, British Cycling selects national teams, including the GB cycling team for races in Great Britain and for international competitions. It is responsible for overseeing the UK's international cycling interests.

British Cycling is funded through several revenue streams. Approximately $45 \%$ of the organisation's funding on current figures is comprised of grants and awards from public bodies such as UK Sport and Sport England. British Cycling generates approximately 55\% of its funds from private sources including membership fees, event levies and sponsorships from commercial parties.

From when Varnish joined the development programme in 2006 until the relationship came to an end, an athlete entered into an Athlete Agreement with British Cycling. The terms were essentially the same over the years although they evolved. By being a member of the development programme, Varnish was eligible to apply to UK Sport for a means tested grant, which she did.

Varnish received funding via an Athlete Performance Award (hereinafter "APA") from the UK Sport, where an APA is a means tested contribution towards an athlete's living and sporting costs to enable the athlete to train full or part-time with the support of the 
sport and its World Class Programme.

Alongside the training and equipment available to cyclists, British Cycling has a dedicated support team to assist the cyclists off the track. This includes dedicated bike mechanics available for the cyclists during training. British Cycling also provides onsite physiotherapy, massage and doctor services to the cyclists as and when required. That is only one part of the physiological services that the first respondent provides to the cyclists. Nutritionists, biomechanical experts, psychologists and lifestyle management experts are also provided to supplement the coaching, training and on track services. Cyclists are provided with personal accident insurance and travel insurance for training camps and events, with all foreign travel and accommodation paid for.

The value of these services was estimated at $£ 85,000$ over four years for a Junior Academy member, $£ 350,000$ over four years for a Senior Academy member and a value of $£, 600,000-$ $£, 700,000$ over a four-year period for a podium rider.

The Varnish's relationship with British Cycling is reflected in the "Athlete Agreement". It is agreed that the claimant had the benefit of an Athlete Agreement continuously from 2005 until the relationship came to an end when athlete was informed, she was no longer part of the Podium Programme from 31 March 2016, by a letter dated 14 March 2016. Although Varnish received the benefit of services under the Athlete Agreement from British Cycling, there was no entitlement to sums of money under that Agreement. (Case No. 2404219/2017)

As reflected by the authors in the article "The Jess Varnish Decision - Why British Athletes Are Still Not Considered "Employees" And What It Means for Athletes and NGBs" Varnish commenced legal proceedings against British Cycling and UK Sport after she was dropped from the UK's cycling World Class Programme (hereinafter "WCP") after failing to qualify for the 2016 Rio Olympics. Varnish claims she was dropped from the elite squad because of her public criticism of British Cycling coaches, however British Cycling maintains its decision was entirely performance related. In early 2016, Varnish had alleged that she was subjected to discrimination and bullying by British Cycling coaches. (Fursdon, Lewis \& Westerman, 2019)

According to the "Report of the independent review panel into the climate and culture of the world class programme in British Cycling" Good governance was lacking at British Cycling Board level in relation to how it managed the culture and behaviors within the WCP, although the Panel when considering a number of areas in terms of discrimination stated:

"In terms of coaching, equipment, or selection, the Panel do not find that there was discrimination because of gender. The WCP was (and is) committed to performance outcomes. It does not fit with that central aim for an athlete not to be afforded the ability to perform well because of their gender. In coming to that finding, the Panel considered whether there may have been a subconscious motivation of sex discrimination in play. One member of the WCP support staff informed the Panel that they thought that was the case. However, on balance, the Panel rejects that contention given the medal-performance driven aims of the WCP is gender-neutral." (Phelps et al., 2017)

Following that decision to drop Varnish from the Great Britain team ahead of the Rio Olympics for performance reasons, Varnish issued a claim against British Cycling and UK Sport for unfair dismissal, direct sex discrimination, victimisation and unlawful detriment 
for having made protected disclosures (known as "whistleblowing"). To pursue these claims Varnish had to prove that she was an employee and/or a worker of British Cycling and/or UK Sport (Fursdon, Lewis \& Westerman, 2019).

Both British Cycling and UK Sport disputed that the claimant was employed by them. Both respondents disputed the claimant was a worker as defined by section 230(3) ERA 1996 for the first or second respondent. Both respondents disputed she was eligible to bring her claim under the definition of section 83(2)(a) Equality Act 2010. (Case No. 2404219/2017)

As mentioned by Fursdon, Lewis and Westerman, a hearing was held in December 2018 to determine this preliminary issue and, the answer from the Tribunal in January 2019 was a resounding "no": it was held that Varnish was neither an employee nor a worker of British Cycling or UK Sport (Fursdon, Lewis \& Westerman, 2019). Accordingly, the Tribunal did not have jurisdiction to hear her case and her claim had failed at the first hurdle.

In Varnish's case, Judge identified and applied three key elements of an employment relationship derived from the case of Ready Mixed Concrete (South East) Ltd v Minister of Pensions and National Insurance:

a) Mutuality of obligation, also known as the "wage/work bargain", is the obligation on the part of the employer to provide work and a corresponding obligation on the part of the employee to accept and perform the work in exchange for remuneration, usually but not necessarily in the form of wages. In relation to British Cycling, Judge ruled that work was neither provided to or undertaken by Varnish; instead Varnish "agreed to train in the hope she would be selected to compete for the British Cycling team". The Judge also found that Varnish did not receive remuneration from British Cycling. Varnish had received an APA however this was provided by UK Sport and funded by the National Lottery. Moreover, this funding had to be applied for and its discretionary nature indicated that it was a means tested grant and not a wage. Judge found that there was no day-to-day relationship between Varnish and UK Sport. It was held that Varnish "was simply provided with a tax-free grant [the APA] to enable her to full her dreams as an athlete. UK Sport did not provide her with work" and the grant was not based on past work but rather on her future potential. Accordingly there was no mutuality of obligation.

b) Judge also stressed that the requirement for personal performance of the employment contract must be linked to the underlying work of the contract. She restated that in relation to British Cycling, Varnish was personally performing a commitment to train, not work and that this "does not amount to personal performance consistent with a finding of a contract of employment". Similarly the Judge rejected any personal performance in relation to UK Sport.

c) The Judge considered the relationship between British Cycling and Varnish and found that control was a significant feature. Her judgment highlighted that many aspects of Varnish's life were closely controlled by British Cycling, such as what she ate and how, when and where she trained. However, despite its control over her, the absence of the other indicators of an employment relationship meant that Varnish was not an employee of British Cycling. Judge Ross stated that UK Sport had no direct control over Varnish save for the requirement under the terms of the APA grant that she carry out a maximum of three National Lottery appearance days every year. This clause was for the benefit of 
the National Lottery rather than UK Sport and therefore UK Sport did not exert control over Varnish. (Fursdon, Lewis \& Westerman, 2019).

The Judge identified that an "irreducible minimum" of each of these elements was necessary to create a contract of service.

As a result, on 16 January 2019, Jessica Varnish, the 28-year-old former Great Britain track cyclist and European team sprint champion, lost an employment claim against British Cycling and UK Sport. In the case, the Manchester Employment Tribunal (the Tribunal) ruled that Varnish was

neither an employee nor a worker of British Cycling or UK Sport.

The ruling in the Varnish case provides a degree of clarity for NGBs and athletes as to their relationship and respective rights and responsibilities. However, the public discourse around employee/worker status continues to evolve as cases on the topic move through the courts, attempting to dene our modern working relationships. (Fursdon, Lewis \& Westerman, 2019)

Controversial issues on the employment status of athletes are now and then also raised in the United States collegiate sports governed by the National Collegiate Athletic Association (hereinafter "NCAA"), where NCAA is a nonprofit organization that regulates student athletes from up to 1,268 North American institutions and conferences. Weston refers to the recent case law: Jenkins v. NCAA, Kavanagh v. Trs. of Boston Univ., Korellas v. Ohio State Univ., on whether scholarship athletes are deemed to be university employees (Weston, 2020). As professor states: "the litmus test of whether a college athlete should be considered an employee for workers' compensation purposes is the existence of a quid pro quo arrangement. When competent evidence shows that the student's performance of athletic services is given as consideration for financial aid, the courts should recognize the student's status as a student-employee (albeit the National Labor Relations Board has found scholarship football players at a private Division I university are not employees for purposes of the National Labor Relations Act.) An objective appraisal of the relevant cases reveals the better reasoned approach: the ordinary athletic scholarship does indeed create an employer-employee relationship. For a variety of unarticulated reasons - foremost among them the fear of uncharted waters - it is not surprising that the courts have tended to refuse to hold that the amateur athletes are really employees. It is an uncomfortable and unsettling realization that our scholarship athletes are really employees, but it is a conclusion that an honest appraisal compels. And it is a conclusion from which a number of beneficial consequences will undoubtedly flow, contributing to the reform of a system much in need of constructive change. If scholarship athletes really are university employees, they are not "amateurs" as that term is commonly defined. To a certain extent this means that big-time college sports would be openly professionalized." (Weston, 2020)

\section{Specifics of Sports Tax Law}

In the tax system of Latvia, the employer calculates, withholds and pays into the state budget the mandatory state social insurance contributions (MSSIC) and personal income tax (PIT) on the basis of the athlete's remuneration.

Section 1, Clause 2, Sub-clause "s" of the Law on State Social Insurance stipulates that an 
employee shall be a professional athlete (Likums par valsts sociālo apdrošināšanu, 1998). Section 14, Paragraph 20 of the Law on State Social Insurance stipulates that the object of mandatory contributions for a professional athlete shall be EUR 860 (Likums par valsts sociālo apdrošināšanu, 1998). The object of mandatory contributions is determined in proportion to the period, during which a professional athlete has the status of an employee, as well as not applied for the calendar days of the taxation year, when a professional athlete is on parental leave, when he (father of a child) has been granted leave due to the birth of a child, when he is on unpaid holiday, which has been granted to a professional athlete, under whose care and supervision a child in care has been assigned prior to the approval of adoption in the court, or for the calendar days of temporary incapacity of work, and maternity leave, which have been covered by the "B" sick-leave certificate.

At the moment, the MSSIC rate applicable to a professional athlete insured according to all the kinds of state social insurance is 34.09\%: including 23.59\% - the employer's share, $10.5 \%$ - the employee's share (Valsts ieñemumu dienests, 2021).

A professional athlete makes the MSSIC through the employer - the employer withholds the contributions to be made by the employee and pays these amounts into the relevant budget.

It is important that the part of salary exceeding 860 euros is not an object of the MSSIC, and the exceeded amount is not a subject of the MSSIC.

Section 14, Paragraph 21 of the Law on State Social Insurance stipulates that, if the object of mandatory contributions calculated for a professional athlete is lower than 860 euros, mandatory contributions from the difference between 860 euros and remuneration of the professional athlete's remuneration shall be calculated and settled from own funds by the employer (Likums par valsts sociālo apdrošināšanu, 1998).

From 1 January 2021, salaries of professional athletes are subject to a special PIT of 20\% in Latvia (Valsts ieñēmumu dienests, 2021). At the moment, professional athletes form the only group of employees subject to PIT of $20 \%$ regardless of the amount of salary. When calculating PIT of the remuneration of a professional athlete, the disburser of the income is entitled to apply the rate of $20 \%$ to the entire monthly income within a year regardless of whether it has been presented as the main source of income in the athlete's electronic personal income tax logbook. Disburser of the income is also entitled to apply the rate of $20 \%$ to the remuneration of a professional athlete - non-resident.

If a professional athlete has not specified the employer as his/her main source of income in the electronic personal income tax logbook, the monthly income (salary) is not subject to the projected non-taxable minimum (if it applies) and allowances for dependents.

The authors consider that the aforementioned changes in the tax will facilitate the use of the contracts of employment in professional sports, because the majority of athletes have entered into royalty contracts or micro-enterprise contracts with the sports clubs. Thus, they are not subject to changes in the income tax rate.

For example, so far, the contract of a payer of micro-enterprise tax has been much more favourable for both parties, since the tax share to be paid accounted for $15 \%$ up until 2021. Whereas, from 2021, the applicable rate is $25 \%$, however, as soon as the annual income exceeds 25,000 euros, the rate hits $40 \%$.

Furthermore, the greatest benefit of the aforementioned tax changes is the following: if a professional athlete has entered into a contract of employment with the employer, the 
athlete is subject to social insurance and saves money for the pension in the future, as well as, in accordance with Section 149 of the Labour Law, obtains the right to annual paid leave (Darba likums, 2002).

Having studied the labour and tax issues of the employment of athletes in Latvia, the authors decided to pay attention to the tax features of sports federations and societies.

Section 10, Paragraph Two of the Sports Law stipulates that a sports club is an association in which natural persons and legal persons have united in order to implement their interests in a specific type of sport and to promote its development (Sporta likums, 2002). Paragraph Three of the aforementioned Section stipulates that a sports federation is an association which is composed of sports clubs and other legal persons, the work of which is associated with a specific type of sport or field of activities, and the purpose of which is to manage and co-ordinate the work in the relevant type of sport or field of activities, as well as to represent such type of sport or field of activities in the relevant international sports organisations (Sporta likums, 2002).

Accordingly, the Sports Law stipulates that sports clubs and sports federations are associations. Section 3 of the Associations and Foundations Law stipulates that an association and a foundation obtain the status of a legal person at the moment when it is entered into the Register of Associations and Foundations (Biedrību un nodibinājumu likums, 2004).

While researching the activity of a sports federation from the tax law aspect, the authors found out that sports clubs and sports federations are engaged in economic activity, while their accounting records are not always sufficiently transparent for a person qualified in accounting matters to be able to obtain a true and fair view of the company's financial situation on the balance date, its performance, cash flow over a certain period of time, as well as to find the beginning of each economic transaction and track down its course (Likums par grāmatvedību, 1993).

For example, on 23 February 2016, administrative case No. A420380514 association "Stiprinieku republika" [“Republic of Muscle Men”] (previous name up to 8 January 2015 - "Latvijas Spēka atlētu federācija" ["Latvian Federation of Powerlifters"]) against the tax administration was adjudicated in the Administrative District Court Riga Courthouse (,Stiprinieku republika” pret nodokļu administrāciju, 2016).

The subject of this particular dispute was whether the tax administration has justifiably denied the association from pre-tax deductions from the amount of value added tax payable into the budget on the basis of the invoices for advertising services issued on behalf of the direct business partner.

Thus, it is necessary to ascertain whether the user of the pre-tax deduction right has received the service specified in the invoice at all. If it is found that the service was never received, the taxpayer should be denied its rights to pre-tax deductions without detailed consideration of the formal requirements related to pre-tax deduction, since the transaction has actually only taken place on the basis of the use of these rights. If it is found that the user of the pre-tax deduction right has received the service specified in the invoice, it is further necessary to ascertain whether this service has been received directly from the VAT-taxable person specified in the transaction documents. If it is found that the person specified in the invoice has not provided the service in question, it is necessary to ascertain whether the user of the pre-tax deduction right knew or was supposed to know 
that the transaction was related to abuse of the value added tax system.

The contract stipulates that the direct business partner undertakes to provide activities related to the creation, development, arrangement and coordination of advertisement ideas, attraction of media and sponsors and other activities related to the event's publicity, services for the competition organised by the client during the 2013 season. The invoices contain a general reference to the advertising services, whereas the acceptance-delivery reports contain an indication on the advertising campaigns of the "Latvian Muscleman Championship 2013" for teams, closing ceremony, super final, sections one through five and highlanders' games.

Having assessed the evidence of the case, the court considered that such general references and specifications in written evidence deny identification of the specific received service. The court rejected as unjustified the taxpayer's argument concerning the interest of the provider of advertising services to comply with confidentiality as a reason for such a lack of accuracy. In this specific case, it was not required to describe how exactly the business partner created ideas, developed advertisement design, conducted negotiations regarding arrangement of the advertisement or performed other activities either in the contract, or the invoices, or the acceptance-delivery reports. In the court's opinion, it is reasonable to expect that these documents stipulate exactly what services are expected from the direct business partner, what services have been provided by the direct business partner and what services have been recognised by the association in the acceptance-delivery reports "planned and performed in good quality and accepted without any claims".

Having assessed the evidence of the case, the court had no doubt that such services had been received, while doubt as to whether these services were received from the person the direct business partner - was present.

The court found that the taxpayer, its direct business partner and business partner of the following section of the chain were not able to provide detailed, logical, consequent and internally consistent explanations regarding the course of the service provision, thus, the court came to the conclusion that the taxpayer had engaged itself in non-documented agreements with persons, which did not represent the direct business partner in any way, as well as engaged in drawing up false business documents regarding works not actually performed by this company. The entirety of the circumstances of the case indicates that the taxpayer had been aware that the works were actually performed by other persons, but had drawn up false documents with the direct business partner to gain undue fiscal advantages.

\section{Conclusions}

Issues arising from a noticeably incorrect definition of a professional athlete in the Sports Law (legislative act) and the actual employment relationship could be resolved in two ways. One of the ways could be, to oblige clubs to comply with the requirements of the Sports Law, thus in the future athletes would be employed on the basis of an employment contract - at least such a mechanism could be introduced at the level of the Latvian Olympic unit. However, in that case it would be the creation of a coercive mechanism, which has obviously not been introduced in Latvia for the last 19 years since Sports Law of the Republic of Latvia came in to legal force. Which means the whole sports 
management system in Latvia should be reformed in order for professional athlete to perform his duties under the Labour law provisions. A completely different approach would be to create an appropriate regulation of the employment of athletes, to provide a definition of a professional athlete suitable for the real situation, which would allow Latvian athletes to be professional, even without working on the basis of an employment contract.

Determining an appropriate basis for the employment of athletes would not only give athletes official professional athlete status, but also guarantees and certainty. Researching on the issues of professional athletes' employment in other European and not only countries, authors concluded, that there is a common understanding that professional athletes' employment contracts show signs of employment, but due to specific industry, national and international federation regulations, professional athletes' employment requires special regulation.

As for taxation, in international practice there are many tools that allow to plan and optimize the tax burden on individual taxpayers. In particular, the requirements of the local legislation of different countries allow to receive various benefits and apply reduced rates under certain conditions, for example, when reinvesting the income received within the same country. However, the often-used schemes are openly aggressive and can be challenged by the tax authorities, which will lead to the accrual of fiscal penalties, as well as damage the professional reputation of the athlete (Ganin \& Polugodina, 2009). Therefore, the theoretical and practical risks associated with the requirements of the laws of different countries should be carefully assessed at any time.

The Republic of Latvia is currently in the process of an enormous tax reform that has affected the sports industry as well. The opinions in regards the reform of financial and sports experts were divided. However, it is too early to draw conclusions about the changes that have come into force. Nevertheless, one thing is clear, for the sustainable development of the sports industry in Latvia, changes are needed.

Thus, the taxation in sports is a very specific area, which can be understandable and transparent only in the case of international interinstitutional cooperation.

\section{References}

Administratīvā lieta Nr.A420380514 biedrība „Stiprinieku republika” pret nodokḷu administrāciju (Administratīvā rajona tiesa, 2016)

Biedrību un nodibinājumu likums (2004) Retrieved from: https://likumi.lv/ta/id/81050-biedribu-unnodibinajumu-likums

Bodleian Libraries (2021) United Kingdom Law: Legal system. Retrieved from: https://ox.libguides.com/c.php?g=422832\&p=2887374

Colucci, M., \& Hendrickx, F., (eds.). (2014) Regulating employment relationships in professional football. A comparative analysis. Sports Law and Policy Centre Srls.

Colucci, M., (2014) Employment relationships at national level: Italy. In M. Colucci and F. Hendrickx (eds.), Regulating employment relationships in professional football. A comparative analysis. (pp. 201-217), Sports Law and Policy Centre Srls.

Darba likums, 2002. Retrieved from: https://likumi.lv/ta/en/en/id/26019-labour-law

Dynowski P., \& Sałajczyk, M., (2020) The Sports Law Review: Poland. Retrieved from: https://thelawreviews.co.uk/title/the-sports-law-review/poland 
Fursdon C., Lewis R., Westerman C. (2019). “The Jess Varnish Decision - Why British Athletes Are Still Not Considered "Employees" And What It Means For Athletes And NGBs". Retrieved at: https://www.lawinsport.com

Ganin A., Polugodina E. (2009). Bremya pobedy. Retrieved from: https://www.bolshoisport.ru/articles/bremya-pobedy

Gardiner S., O’Leary J., Welch R., Boyes S. \& Naidoo U. (2012) Sports Law. (4th ed.) Routledge.Rodríguez, R.D.B., (2014) Employment relationships at national level: Mexico. In M. Colucci and F. Hendrickx (eds.), Regulating employment relationships in professional football. A comparative analysis. (pp. 233-249), Sports Law and Policy Centre Srls.

Hendrickx F., (2017) What if sport and labour law have become interlocked? Retrieved from: https://www.ercprague2017.cz/wp-content/uploads/2017/02/Hendrickx What-if-sport-andlabour-law-have-become-interlocked.pdf

Latvijas Republikas Ministru kabineta tiesību aktu projekti (2021) Sporta politikas pamatnostādnes 2021.-2027.gadam. Retrieved from: http://tap.mk.gov.lv/lv/mk/tap/?dateFrom $=2020-07-10 \& d a t e T o=2021-07-$ $10 \&$ text $=$ Sporta + politikas + pamatnost $\% C 4 \% 81$ dnes\&org $=0 \&$ area $=0 \&$ type $=0$

Likums par grāmatvedību (1993) Retrieved from: https://likumi.lv/ta/id/66460-par-gramatvedibu

Likums par valsts sociālo apdrošināšanu (1998). Retrieved from: https://likumi.lv/ta/id/45466-par-valstssocialo-apdrosinasanu

Möller, K.O., (2020) Sweden sports law. Retrieved from: https://nordialaw.com/globalassets/news/2019-12december/sweden-sports-law-2020.pdf

Phelps A., Kelly J., Lancaster S., Mehrzad J., Panter A. (2017). Report of the independent review panel into the climate and culture of the world class programme in British Cycling" Retrieved at: https://www.sportsthinktank.com/uploads/cycling-independent-review.pdf

Ready Mixed Concrete (South East) Ltd v Minister of Pensions and National Insurance. 2 QB 497 (1968). Retrieved at: https://www.bailii.org/ew/cases/EWHC/QB/1967/3.html

Sporta likums, 2002. Retrieved from: https://likumi.lv/ta/en/en/id/68294-sports-law

Varnish vs. British Cycling/UK Sports. Case No. 2404219/2017 (2017). Retrieved at: https://assets.publishing.service.gov.uk/media/5c4882bbed915d3893bbdf14/Miss I Varnish v The British Cycling Federation t.a British C 24042192017 - Reserved Judgment.pdf

Weston M.A. (2020) Legal Relationships in Amateur Sports. Sports Law: Cases and Materials (9th ed.), Pepperdine University Legal Studies Research Paper No. 2020/1, Retrieved at: https://ssrn.com/abstract $=3514958$

Valsts ieņēmumu dienests (2021) Informatīvais materiāls "Nodokḷu piemērošana profesionālo sportistu ienākumam" Retrieved from: https://www.vid.gov.lv/sites/default/files/info materials nodoklu piemerosana profesionalo sportistu ienakumam.pdf 